\title{
Molecular and Pathogenic Characterization of Fusarium redolens, a New Causal Agent of Fusarium Yellows in Chickpea
}

Daniel Jiménez-Fernández, College of Agriculture and Forestry (ETSIAM), University of Córdoba (UCO), Campus de Rabanales, Ctra. Madrid-Cádiz, 14071 Córdoba, Spain; Juan A. Navas-Cortés and Miguel Montes-Borrego, Institute for Sustainable Agriculture (IAS), Spanish National Research Council (CSIC), 14080 Córdoba, Spain; Rafael M. Jiménez-Díaz, ETSIAM, UCO, and IAS, CSIC; and Blanca B. Landa, Institute for Sustainable Agriculture (IAS), Spanish National Research Council (CSIC), 14080 Córdoba, Spain

\begin{abstract}
Jiménez-Fernández, D., Navas-Cortés, J. A., Montes-Borrego, M., Jiménez-Díaz, R. M., and Landa, B. B. 2011. Molecular and pathogenic characterization of Fusarium redolens, a new causal agent of Fusarium yellows in chickpea. Plant Dis. 95:860-870.

The association of Fusarium redolens with wilting-like symptoms in chickpea in Lebanon, Morocco, Pakistan, and Spain is reported for the first time, together with the molecular and pathogenic characterization of isolates of the pathogen from chickpea of diverse geographic origin. Maximum parsimony analysis of sequences of the translation elongation factor $1 \alpha$ (TEF-1 $\alpha)$ gene grouped all $F$. redolens isolates from chickpea in the same main clade. Pathogenicity assays using three chickpea cultivars and isolates from different geographic origins indicated that $F$. redolens is mildly virulent on chickpea. Moreover, infection of chickpea by $F$. redolens induces a disease syndrome similar to

that caused by the yellowing pathotype of $F$. oxysporum f. sp. ciceris, including leaf yellowing and necrosis that develop upward from the stem base, and premature senescence of the plant. In contrast, F. redolens does not cause discoloration of the vascular tissues in chickpea but does cause brown necrotic lesions in the tap root and necrosis of lateral roots. $F$. redolens is not easily differentiated from $F$. oxysporum $\mathrm{f}$. sp. ciceris using morphology-based diagnosis, and the two species cause similar symptoms on chickpea; therefore, the use of molecular protocols should help to avoid misdiagnoses of Fusarium yellows in chickpea.
\end{abstract}

Chickpea (Cicer arietinum L.) is an important source of human food and animal feed that also helps in the management of soil fertility, particularly in dry areas. In the European Union, chickpea production is concentrated in the Mediterranean Basin, with Spain being the main producer (16). In Spain, most chickpea crops are located in the Córdoba and Sevilla provinces of Andalusia (45).

Chickpea can be severely affected by several diseases of diverse etiology, among which Fusarium wilt, caused by Fusarium oxysporum f. sp. ciceris Matuo \& K. Sato, is the most important soilborne disease limiting chickpea production in the Mediterranean Basin and the Indian subcontinent $(26,39,47)$. Fusarium wilt-affected chickpea can show an early wilting syndrome a few weeks after sowing or a late wilting one later in the season. Early wilt is characterized by flaccidity of individual leaves followed by a dullgreen discoloration, desiccation, and collapse of the entire plant; whereas late-wilted plants exhibit drooping of the petioles and leaflets, followed by yellowing and necrosis of foliage $(27,29)$. Although both syndromes are a direct consequence of vascular infection by the pathogen, they may also be caused by different plant pathogens and, as a consequence, be misidentified as Fusarium wilt if wrongly diagnosed. For instance, several plant viruses can induce leaf yellowing and flaccidity in chickpea $(29,35,51)$. Similarly, plants showing leaf yellowing and necrosis are frequently found in chickpea crops affected by the wilt and root rot disease complex that has been reported in California, India, and southern Spain associated with infections by F. oxysporum f. sp. ciceris, F. solani f. sp. pisi (F.R. Jones) W.C. Snyder \& H.N. Hansen, F. solani f. sp. eumartii (C.W. Carp.) W.C. Snyder \& H.N.

Corresponding author: B. B. Landa, E-mail: blanca.landa@ias.csic.es

* The $\boldsymbol{e}$-Xtra logo stands for "electronic extra" and indicates that Figure 6 appears in color online.

Accepted for publication 18 March 2011.

doi:10.1094/PDIS-12-10-0946

(c) 2011 The American Phytopathological Society
Hansen (= F. eumartii C.W. Carp.), and Macrophomina phaseolina (Tassi) Goid. $(23,37,51,59,63)$. In those cases, as well as in chickpea plants affected by abiotic stresses, isolations in pure culture often yield nonpathogenic isolates of $F$. oxysporum or other Fusarium spp. with morphology similar to that of the $F$. oxysporum species-complex $(1,36,59 ;$ R. M. Jiménez-Díaz and B. B. Landa, unpublished results). Consequently, isolating $F$. oxysporum-like fungi from chickpea showing wilt-like symptoms, even if performed from upper stem tissues, does not guarantee recovery of $F$. oxysporum f. sp. ciceris and can lead to misdiagnosis of Fusarium wilt if isolates are not further characterized by morphological or molecular examinations.

Typically, morphology-based diagnoses of Fusarium spp. are hugely challenging due mainly to the use of different taxonomic systems, the reduced number of mycologists with adequate experience for identifying these fungi, and the lack of sufficiently informative morphological features. Moreover, the morphologybased identification of Fusarium spp. relies on a limited number of taxonomic characters of minor differences in morphology and varying importance in different Fusarium spp. (42). In addition, the microscopic traits are sensitive to the influence of environmental conditions, and their plasticity and intergradation make them prone to misinterpretation (42). For example, differentiating $F$. redolens from $F$. oxysporum can sometimes be especially difficult because it is based mainly on size differences of their macroconidia (22) and is further complicated by the presence of intermediate conidial forms (2). For these reasons, the taxonomic position of $F$. redolens has always been problematic. Thus, Booth (10) treated this fungus as a variety of $F$. oxysporum, whereas Nelson et al. (50) considered $F$. redolens a synonym of $F$. oxysporum. However, use of DNA-based methodologies made it recently possible to clearly differentiate between these two species and also revealed that $F$. redolens and the $F$. oxysporum species complex lack a sister group relationship $(4,17,53,61,62)$.

As in the $F$. oxysporum complex, $F$. redolens harbors isolates that can cause a wide range of diseases, including cortical rot, seedling damping-off, and wilt diseases $(10,20,21)$. Furthermore, differentiating between diseases caused by $F$. redolens and $F$. oxysporum has also been complicated because they can induce symp- 
toms similar to those that occur with asparagus crown and root rot associated with decline of the crop (65). Similarly, $F$. redolens occurs in association with $F$. oxysporum f. sp. pisi in wilt-affected pea but each of these fungi can cause wilting in this plant separately and induce symptoms indistinguishable from one another (10).

Currently, $F$. redolens and $F$. oxysporum are most easily diagnosed based on restriction fragment length polymorphism (RFLP) patterns of their rRNA internal transcribed spacer (ITS) regions $(61,62)$. However, this ITS-RFLP assay does not differentiate $F$. redolens from $F$. hostae, a close relative $(5,19)$. That technique is also expensive and technically demanding because it calls for the use of three restriction enzymes. More recently, development of species-specific polymerase chain reaction (PCR) assays for the identification of $F$. hostae, $F$. redolens, and $F$. oxysporum have facilitated their diagnosis and helped to sort out some isolates originally misidentified $(5,15,31,46)$.

This study was conducted to comparatively determine the nature of Fusarium spp. associated with leaf yellowing in chickpea in different countries. The association of $F$. redolens with chickpea showing wilting-like symptoms in Spain and other countries is reported for the first time. Furthermore, chickpea $F$. redolens isolates were characterized molecularly and pathogenically and then positioned in relation to other Fusarium spp. infecting chickpea, other $F$. redolens isolates infecting different hosts, and the $F$. oxysporum-complex clade.

\section{Materials and Methods}

Fusarium isolates from chickpea. A wilt-like syndrome was observed affecting chickpea crops during disease surveys in 12 commercial fields in Córdoba, Jaén, Sevilla, and Granada provinces at Andalusia, southern Spain. Affected plants showed yellowing or wilting and brown discoloration of vascular tissues. Pieces (5 cm long) were sampled from the uppermost main stem of diseased plants and used for isolations. Tissues were surface disinfested $(0.5 \% \mathrm{NaOCl}, 2 \mathrm{~min})$, cut into 5 -mm-long pieces, plated onto Fusarium-selective V8 juice-oxgall-pentachloronitrobenzene agar (11), and incubated for 7 days at $25 \pm 1{ }^{\circ} \mathrm{C}$ and a 12-h photoperiod of fluorescent and near-UV light at $36 \mu \mathrm{E} \mathrm{m}^{-2} \mathrm{~s}^{-1}$. Examination of cultures indicated that profuse growth of a fungus morphologically similar to $F$. oxysporum (49) occurred from the vascular ring at the cut ends of the stem pieces, suggesting vascular infection of the affected plants. In total, 84 Fusarium spp. isolates were recovered and subsequently characterized to species using molecular protocols (see below). Additionally, 80 chickpea isolates of Fusarium spp. provided by scientists around the world were used in the study (Tables 1 and 2). Those latter isolates had originally been assigned to the forma specialis ciceris by the source laboratory but we consistently failed to amplify the 1,500-bp $F$. oxysporum f. sp. ciceris specific-PCR marker (32) (see below).

All the above referred isolates are deposited in the culture collection of Departamento de Protección de Cultivos, Instituto de Agricultura Sostenible (IAS-CSIC), Córdoba, Spain. All cultures were single spored before storage in sterile soil tubes at $4{ }^{\circ} \mathrm{C}$ and in $35 \%$ sterile glycerol in water at $-80^{\circ} \mathrm{C}$ for long-term storage.

Fungal growth and DNA extraction. A small agar piece from actively growing Fusarium cultures in potato-dextrose agar (PDA) (Difco Laboratories, Detroit) was placed onto a film of sterile cellophane layered over a plate of PDA and incubated for 3 to 4 days at $25 \pm 1{ }^{\circ} \mathrm{C}$ and a 12 -h photoperiod of fluorescent and nearUV light at $36 \mu \mathrm{E} \mathrm{m}^{-2} \mathrm{~s}^{-1}$. Then, mycelia growing over the cellophane surface were scraped off using a sterile scalpel, lyophilized, and stored at $-20^{\circ} \mathrm{C}$ until used.

Fungal DNA was extracted from $50 \mathrm{mg}$ of lyophilized mycelium using the G-SpinTM IIp Plant Genomic DNA extraction kit (Intron Biotechnology, Korea) and the Fast Prep System Bio 101 (Qbiogene, Illkirch, France), according to Jiménez-Fernández et al. (31). DNA quality was assessed by gel electrophoresis and staining with ethidium bromide. All DNA samples were accurately quantified using the Quant-iT DNA Assay Kit Broad Range fluorometric assay (Molecular Probes Inc., Leiden, The Netherlands) and a Tecan Safire fluorospectrophotometer (Tecan Spain, Barcelona, Spain) (38). DNA was diluted with sterile, ultrapure water (SUW) to $20 \mathrm{ng} / \mu \mathrm{l}$.

Molecular characterization of Fusarium spp. isolates. Fusarium spp. isolates from chickpea in the study were characterized as $F$. oxysporum f. sp. ciceris or F. oxysporum by means of specificPCR markers developed by Jiménez-Gasco and Jiménez-Díaz (32) (FOC-PCR), and Jiménez-Fernández et al. (31) (FO-PCR), respectively. A F. redolens-diagnostic, specific-PCR assay developed by Bogale et al. (9) was used to confirm results of phylogenetic analysis of the Fusarium spp. translation elongation factor $1 \alpha$ (TEF- $1 \alpha)$ gene (see below). The set of primers LR3 (5'-CCGTGTTTCAAG ACGGG-3') (64) and CS33 (5'-CGAATCTTTGAACGCACATTG$\left.3^{\prime}\right)$ (60) that amplify a 900-bp region of the large subunit of the rRNA was included in the assays as an internal positive control for successful PCR amplification (Fig. 1).

All Fusarium isolates that were diagnosed as F. redolens were further characterized by RFLP assays of the ribosomal intergenic spacer region (IGS) as previously described $(13,14)$. Profiles yielded from these assays were compared with the RFLP-IGS profiles of $15 F$. oxysporum f. sp. ciceris isolates representative of the eight pathogenic races (i.e., races $0,1 \mathrm{~A}, 1 \mathrm{~B} / \mathrm{C}, 2,3,4,5$, and 6 ) of this pathogen (30) and three isolates of $F$. oxysporum nonpathogenic to chickpea (Table 1). To generate the RFLP-IGS amplicons, a fragment of the IGS sequence of the isolates was amplified using primers PNFo (5'-CCCGCCTGGCTGCGTCCGACTC-3') and PN22 (5'-CAAGCATATGACTACTG GC-3'). The amplicons were then digested with the restriction enzymes AluI, HaeIII, HinfI, MspI, RsaI, ScrFI, and XhoI $(13,14)$. DNA banding patterns were separated by electrophoresis using ReadyAgarose gels, 3\% Trisacetate-EDTA plus ethidium bromide (Bio-Rad, Madrid, Spain), visualized under UV light, and digitalized. Then, images were converted, normalized, and combined using Bionumerics 6.1 software (Applied Maths, Sint-Martens-Latem, Belgium).

For those Fusarium spp. isolates from chickpea that could not be molecularly characterized as $F$. oxysporum f. sp. ciceris or $F$. oxysporum, the translation elongation factor 1-alpha (TEF-1 $\alpha$ ) gene was amplified using primers EF1 (5'-ATGGGTAAGGA(A/G) GACAAGAC-3') and EF2 (5'-GGA(G/A)GTACCAGT(G/C) ATCATG-TT-3') (54). Then, the amplified TEF-1 $\alpha$ sequences were purified using a gel extraction kit (Geneclean turbo; Qbiogene), quantified as described for fungal DNA, and used for direct DNA sequencing using both primers and a terminator cycle sequencing ready reaction kit (BigDye; Perkin-Elmer Applied Biosystems, UK) according to the manufacturer's instructions, on a capillary sequencer (ABI Model 3100 genetic analyzer; Applied Biosystems at STABVIDA (Monte da Caparica, Portugal) sequencing facilities. The TEF- $1 \alpha$ sequences of Fusarium spp. were deposited in GenBank (accessions GU126796 and HQ731047 to HQ731068; Table 2). A BLAST search was done against sequences in the FUSARIUM-ID v.1.0 database (http://fusarium.cbio.psu.edu) that represent a phylogenetically diverse selection of TEF- $1 \alpha$ sequences from the genus Fusarium to characterize unidentified Fusarium isolates (18), as well as against the GenBank database.

For phylogenetic analysis, $F$. redolens sequences were edited and aligned with representative homologous sequences from FUSARIUM-ID and GenBank databases, as well as Fusarium TEF-1 $\alpha$ sequences from Baayen et al. (5), Jiménez-Gasco et al. (33), and Gurjar et al. (24) using Bionumerics 6.1 software. These studies were selected because they include the largest number of TEF- $1 \alpha$ sequences of $F$. redolens from different hosts or of Fusarium spp. isolates from chickpea crops ever reported. A phylogenetic tree was generated with the maximum-parsimony method using Bionumerics 6.1. The phylograms were bootstrapped 1,000 times to assess the degree of support for the phylogenetic branching indicated by the optimal trees. $F$. beomiforme strain NRRL25174 was used as an outgroup.

Pathogenicity assay. Seven F. redolens isolates were arbitrarily selected from those in the study and used for pathogenicity assays 
on chickpea. Inocula were produced on autoclaved cornmeal-sand (CMS) in flasks incubated at $25 \pm 1{ }^{\circ} \mathrm{C}$ and a 12-h photoperiod of fluorescent and near-UV light at $36 \mu \mathrm{E} \mathrm{m} \mathrm{m}^{-2} \mathrm{~s}^{-1}$ for 2 weeks, as described before $(39,40)$. Inoculum of $F$. oxysporum f. sp. ciceris race 0 isolate 7802 was also similarly increased and included in the assay for comparative purposes. The infested CMS substrates were mixed thoroughly with an autoclaved soil mixture (clay loam/sand/peat at $1: 1: 1, \mathrm{vol} / \mathrm{vol} / \mathrm{vol})$ at a rate of $1: 12(\mathrm{wt} / \mathrm{wt})$ to reach an inoculum density of approximately $10^{5} \mathrm{CFU} / \mathrm{g}$ of soil for each of the tested and reference isolates. Noninfested CMS mixed with the autoclaved soil mixture at the same rate as above served as the control.

Three Kabuli (ram-head shape, beige seed) chickpea cultivars'P-2245' and 'PV-60' (<30 g per 100 seeds) and 'PV-61' (>44 g per 100 seeds)-were used in the study. All three cultivars are susceptible to different races of $F$. oxysporum f. sp. ciceris (40). Seed were surface disinfested in $2 \% \mathrm{NaOCl}$ for 3 min, germinated, selected for uniformity (length of radicle $=1$ to $2 \mathrm{~cm}$ ), and sown into 15-cm-diameter clay pots (four plants per pot) filled with the CMS-soil mixture of an isolate. Control plants were grown in the noninfested CMS-soil mixture. Plants were incubated in Conviron MTR26 growth chambers (Conviron Ltd., Winnipeg, Canada) ad- justed to $25 \pm 0.2^{\circ} \mathrm{C}, 60$ to $90 \%$ relative humidity, and a 14-h photoperiod of fluorescent light at $360 \mu \mathrm{E} \mathrm{m} \mathrm{m}^{-2} \mathrm{~s}^{-1}$. Plants were watered as needed and fertilized weekly with $100 \mathrm{ml}$ of $0.1 \%$ hydro-sol fertilizer solution (20-5-32 of N-P-K + micronutrients; Haifa Chemicals, Ltd., Haifa, Israel). The experiment consisted of a two-way factorial treatment design with Fusarium isolates and chickpea cultivars as factors. There were five replicated pots (four plants per pot) in a complete block design per treatment combination. The experiment was repeated once.

Disease assessment and data analysis. The incidence and severity of disease reactions were assessed at 2- to 3-day intervals until the end of the experiment, 50 days after inoculation. The severity of symptoms on individual plants was rated on a 0-to-4 scale according to the percentage of foliage with yellowing or necrosis $(0=0,1=1$ to $33,2=34$ to 66 , and $3=67$ to $100 \%$; and $4=$ dead plant $)(40,48)$. Incidence of foliar symptoms $(I ; 0$-to- 1 scale), and severity data ( $S$; 0 -to-4 scale) were used to calculate a disease intensity index (DII) by the equation DII $=(I \times S) / 4$ $(40,48)$. Disease progress curves were obtained from the accumulated DII over time in days from the date of inoculation. Disease development was characterized by three variables associated with disease progress curve: (i) disease onset (DO), established as the

Table 1. Isolates of Fusarium spp. characterized molecularly by restriction fragment length polymorphism of intergenic spacer region of rDNA, with geographic origin, year of isolation, and source

\begin{tabular}{|c|c|c|c|}
\hline Fusarium spp., isolate ${ }^{a}$ & Origin & Year of isolation & Source $^{b}$ \\
\hline \multicolumn{4}{|c|}{ Fusarium oxysporum f. sp. ciceris } \\
\hline \multicolumn{4}{|c|}{ Race 0} \\
\hline 7802 & Córdoba, Spain & 1978 & DPC (IAS-CSIC) \\
\hline 9605 & Tunisia & 1996 & CA, ICARDA \\
\hline L96-5 & Lebanon & 1996 & CA, ICARDA \\
\hline \multicolumn{4}{|l|}{ Race 1B/C } \\
\hline USA-1987-W17 & California, United States & 1987 & DPC (IAS-CSIC) \\
\hline 9602 & Tunisia & 1996 & HMH, INRA \\
\hline \multicolumn{4}{|l|}{ Race $1 \mathrm{~A}$} \\
\hline 8272 & Jaén, Spain & 1982 & DPC (IAS-CSIC) \\
\hline 7989 & Hyderabad, India & 1979 & MPH, ICRISAT \\
\hline \multicolumn{4}{|l|}{ Race 2} \\
\hline 8605 & Kanpur, India & 1986 & MPH, ICRISAT \\
\hline 1992 R2N & India & 1986 & MPH, ICRISAT \\
\hline \multicolumn{4}{|l|}{ Race 3} \\
\hline 8606 & India & 1986 & MPH, ICRISAT \\
\hline 1992 R3N & Gurdaspur, India & 1986 & MPH, ICRISAT \\
\hline \multicolumn{4}{|l|}{ Race 4} \\
\hline 8607 & India & 1986 & MPH, ICRISAT \\
\hline 1992 R4N & Jabalpur, India & 1986 & MPH, ICRISAT \\
\hline \multicolumn{4}{|l|}{ Race 5} \\
\hline USA W6-1 & California, United States & 1988 & DPC (IAS-CSIC) \\
\hline 8012 & Córdoba, Spain & 1980 & DPC (IAS-CSIC) \\
\hline \multicolumn{4}{|l|}{ Race 6} \\
\hline Tonini & California, United States & 1988 & DPC (IAS-CSIC) \\
\hline 8924 & Sevilla, Spain & 1989 & DPC (IAS-CSIC) \\
\hline \multicolumn{4}{|c|}{ F. oxysporum, nonpathogenic } \\
\hline Fo-90105 & Córdoba, Spain & 1990 & DPC (IAS-CSIC) \\
\hline Fo- 8250 & Jaén, Spain & 1982 & DPC (IAS-CSIC) \\
\hline Fo-506 & Tarquinia, Italy & 1989 & DPC (IAS-CSIC) \\
\hline \multicolumn{4}{|l|}{ F. redolens } \\
\hline 7982 & Córdoba, Spain & 1979 & DPC (IAS-CSIC) \\
\hline L96-13 & Lebanon & 1996 & DPC (IAS-CSIC) \\
\hline $34.92 *$ & Morocco & 1996 & CA, ICARDA \\
\hline 9914 & Pakistan & 1999 & SA, NIAB \\
\hline 164-B3 & 'Castro', Córdoba, Spain & 2004 & This study \\
\hline $165-\mathrm{B}$ & ‘Las Fuentes’, Córdoba, Spain & 2004 & This study \\
\hline $167-\mathrm{A} 2$ & 'Monterrite 1', Córdoba, Spain & 2004 & This study \\
\hline $167-B$ & 'Monterrite 2', Córdoba, Spain & 2004 & This study \\
\hline $181-2 \mathrm{~A}, 181-3 \mathrm{~A}$ & 'Montefrío', Granada, Spain & 2004 & This study \\
\hline
\end{tabular}

${ }^{a}$ Race of Fusarium oxysporum f. sp. ciceris was determined by pathogenicity tests on differential chickpea lines before polymerase chain reaction assays $(28,32)$. F. oxysporum isolates listed as nonpathogenic are not pathogenic to chickpea; $*=$ only DNA was available for this isolate.

${ }^{\mathrm{b}}$ Isolates from Italy, Spain, and the United States (California) were obtained from the fungal culture collection of Departamento de Protección de Cultivos (DPC), Institute of Sustainable Agriculture (IAS), Spanish National Research Council (CSIC), Córdoba, Spain. F. oxysporum f. sp. ciceris isolates from India were provided by M. P. Haware (MPH), ICRISAT, Hyderabad, India. Isolates from Tunisia were provided by M. H. Halila (MHH), Institute Nacionale de la Recherche Agronomique, Ariana, Tunisia. Isolates from Lebanon were provided by C. Akem (CA), ICARDA, Aleppo, Syria. Isolate F. redolens 9914 was provided by S. Alam (SA), Plant Health Group, Nuclear Institute for Agriculture and Biology (NIAB), Faisalabad, Pakistan. 
time in days taken for disease severity $>0$; (ii) final disease severity $\left(\mathrm{DII}_{\text {final }}\right)=$ disease severity observed at the final date of disease assessment; and (iii) the standardized area under the disease severity progress curve (SAUDPC), calculated by trapezoidal integration standardized for the duration of disease development in days (43). In addition, at the end of experiments, isolations were made from all plants showing a severity score $<4$ to determine the occurrence and extent of infection by the tested Fusarium isolates. Isolations were done as described above, from the lower four stem internodes and the main root (four segments).

The effects of $F$. redolens isolates and chickpea cultivars on DO, DII $_{\text {final }}$, and SAUDPC as well as on the extent of root and stem colonization by the fungus were determined by multivariate analysis of variance (MANOVA) and univariate standard ANOVA using the general linear model procedure of SAS (Statistical Analysis System v. 9.2; SAS Institute, Cary, NC). Replications within experiments were considered random effects in the analysis. Linear single-degree-of-freedom contrasts were computed to test the effect of selected experimental treatment combinations at $P<0.05$. In addition, a multivariate principal components analysis was performed. A factor loading was considered significant when it was larger than 0.65. The analysis was performed using the PRINCOMP procedure of SAS software. The three disease curve elements (DO, DII final, and SAUDPC) and extent of root and stem colonization by the fungus were used to characterize each $F$. redolens isolate-chickpea cultivar combination.

\section{Results}

Molecular characterization of Fusarium spp. isolates. Six Fusarium isolates (164-B3, 165-B, 167-A2, 167-B, 181-2A, and 181-3A), $7.1 \%$ of the 84 obtained from the 12 surveyed chickpea fields in southern Spain, could not be assigned to F. oxysporum $\mathrm{f}$. sp. ciceris or F. oxysporum using the FOC-PCR (32) and FO-PCR (31) protocols, respectively (Table 1; Fig.1). Conversely, those six isolates were later characterized as $F$. redolens by sequencing of the TEF- $1 \alpha$ gene and BLASTn analysis using the FUSARIUM-ID database (Fig. 2; Table 1). The identity of the six isolates as $F$. redolens was further confirmed by means of the $F$. redolens-specific-PCR (FR-PCR) assay developed by Bogale et al. (9; Fig. 1).

As a follow-up of the study, we characterized a set of 80 Fusarium spp. isolates from chickpea included in a worldwide culture collection that originally had been assigned to $F$. oxysporum $\mathrm{f}$. sp. ciceris by source laboratories but could not be identified to this forma specialis using a specific FOC-PCR protocol (32) (data not shown). Use of the specific FO-PCR and FR-PCR protocols and TEF- $1 \alpha$ gene sequencing and BLASTn analysis against the FUSARIUM-ID database led the 80 Fusarium spp. isolates to be identified as follows: F. redolens, 4 isolates (5.0\%; isolates 9914I, L9613, 34.92, and 7982; Table 1; Fig. 2); F. oxysporum-complex, 64 isolates $(80.0 \%)$; F. solani-complex, 8 isolates $(10.0 \%)$; F. proliferatum, 1 isolate; Neocosmospora vasinfecta, 1 isolate; and an unidentified Fusarium sp. that was close to F. biseptatum and $F$. delphinoides (Table 2). Interestingly, one of the F. redolens isolates (isolate 7982) obtained from wilted chickpea in a field in southern Spain in 1979 was originally assigned to the yellowing pathotype of $F$. oxysporum f. sp. ciceris (34; Fig. 1; Table 1 ).

Amplification of the IGS sequence of 15 isolates of $F$. oxysporum f. sp. ciceris, 3 isolates of nonpathogenic $F$. oxysporum, and $10 \mathrm{~F}$. redolens isolates using primers PN22 and PNFo yielded a DNA fragment of approximately $1,700 \mathrm{bp}$ (Table 1). Digestion of the amplified fragments with each of seven restriction enzymes produced two to four different restriction profiles per PCR product, depending upon the enzyme used. Four different combinations of restriction profiles, representing four IGS types, were identified among the assayed isolates (data not shown). All $F$. oxysporum $\mathrm{f}$. sp. ciceris isolates produced identical IGS type (RFLP-IGS I) regardless of pathogenic race and geographical origin. Also, all $F$. redolens isolates yielded a single IGS type (RFLP-IGS II). The

Table 2. Fusarium spp. isolates originating from chickpea in different countries originally misidentified as Fusarium oxysporum and their most related database accessions based on translation elongation factor 1-alpha (TEF-1 $\alpha$ ) gene and species assignment

\begin{tabular}{|c|c|c|c|c|c|c|c|}
\hline \multirow[b]{2}{*}{ Species } & \multirow[b]{2}{*}{ Isolate } & \multirow[b]{2}{*}{ GenBank $^{\mathrm{c}}$} & \multirow[b]{2}{*}{ Origin } & \multicolumn{2}{|c|}{$\begin{array}{l}\text { Sequence comparison to } \\
\text { FUSARIUM-ID v. } 1.0^{\mathrm{a}}\end{array}$} & \multicolumn{2}{|c|}{$\begin{array}{l}\text { Sequence comparison to } \\
\text { GenBank (BLASTn) }^{\mathrm{b}}\end{array}$} \\
\hline & & & & Most-related & Similarity (\%) & Most-related & Similarity $(\%)$ \\
\hline Neocosmospora vasinfecta & 3Pak & HQ731049 & Pakistan & NRRL 43467 & $99.4(644 / 648)$ & AY381148 & $100(647 / 647)$ \\
\hline \multirow[t]{3}{*}{ Fusarium spp. } & 56.93 & HQ731047 & Morocco & NRRL 53289* & $92.0(555 / 603)$ & EU926322** & $90.5(645 / 713)$ \\
\hline & $\ldots$ & $\ldots$ & $\ldots$ & NRRL 36186** & $91.9(559 / 608)$ & EU926307** & $90.3(635 / 703)$ \\
\hline & $\ldots$ & $\ldots$ & $\ldots$ & NRRL 34027*** & $91.9(559 / 608)$ & $\ldots$ & $\ldots$ \\
\hline \multirow[t]{2}{*}{ F. solani } & $\mathrm{cc} 18 \mathrm{~F}$ & HQ731048 & Israel & NRRL 22278 & $99.9(675 / 676)$ & AB294872 & $90.5(732 / 737)$ \\
\hline & $\ldots$ & $\ldots$ & $\ldots$ & $\ldots$ & $\ldots$ & DQ452423 & $99.1(730 / 737)$ \\
\hline F. solani & cc19Y & HQ731050 & Israel & NRRL 32343 & $99.4(667 / 671)$ & AB498982| & $99.9(693 / 694)$ \\
\hline F. solani & $\operatorname{cc} 43 \mathrm{~A}$ & HQ731051 & Israel & NRRL 32343 & $99.4(667 / 671)$ & AB498982 & $99.9(693 / 694)$ \\
\hline F. solani & $\operatorname{cc} 41 \mathrm{~W}$ & HQ731052 & Israel & NRRL 28555 & $99.7(668 / 670)$ & GU170631 & $99.0(708 / 715)$ \\
\hline F. solani & $2205 \mathrm{I}$ & HQ731053 & Pakistan & NRRL 25388 & $99.9(682 / 683)$ & EU925653 & $99.6(717 / 720)$ \\
\hline F. solani & $\operatorname{cc} 40 \mathrm{~A}$ & HQ731054 & Israel & NRRL 32720 & $99.6(666 / 669)$ & GU170630 & $99.3(705 / 710)$ \\
\hline F. solani & $\mathrm{cc} 20 \mathrm{~B}$ & HQ731055 & Israel & NRRL 32720 & $99.6(666 / 669)$ & GU170630 & $99.3(705 / 710)$ \\
\hline F. solani & $\operatorname{cc} 61 \mathrm{C}$ & HQ731056 & Israel & NRRL 32720 & $100(666 / 669)$ & GU170630 & $99.9(709 / 710)$ \\
\hline F. oxysporum & 808 & HQ731057 & Italy & NRRL 38608 & $100(681 / 681)$ & DQ837688 & $100(691 / 691)$ \\
\hline F. oxysporum & 817 & HQ731058 & Italy & NRRL 39464 & $99.9(685 / 686)$ & DQ837680 & $99.7(696 / 698)$ \\
\hline F. proliferatum & 9009 & HQ731059 & Spain & FD_01389 & $99.26(671 / 676)$ & FJ538244 & $100(678 / 678)$ \\
\hline F. redolens & 9914I & HQ731060 & Pakistan & FD_01103 & $100(665 / 665)$ & GU250584 & $100(703 / 703)$ \\
\hline F. redolens & 34.92 & HQ731063 & Morocco & FD_01103 & $100(665 / 665)$ & GU250584 & $100(703 / 703)$ \\
\hline F. redolens & 7982 & HQ731061 & Spain & FD_01103 & $100(665 / 665)$ & GU250584 & $100(696 / 696)$ \\
\hline F. redolens & 165-B1 & HQ731062 & Spain & FD_01103 & $99.84(663 / 664)$ & GU250584 & $99.9(663 / 664)$ \\
\hline F. redolens & 164-B3 & HQ731065 & Spain & FD_01103 & $100(665 / 665)$ & GU250584 & $100(678 / 678)$ \\
\hline F. redolens & $167-\mathrm{A} 2$ & GU126796 & Spain & FD_01103 & $100(665 / 665)$ & GU250584 & $100(657 / 657)$ \\
\hline F. redolens & 167-B & HQ731068 & Spain & FD_01103 & $100(665 / 665)$ & GU250584 & $100(692 / 692)$ \\
\hline F. redolens & $181-3 \mathrm{a}$ & HQ731066 & Spain & FD_01103 & $100(663 / 663)$ & GU250584 & $100(649 / 649)$ \\
\hline F. redolens & $181-2 \mathrm{~A}$ & HQ731067 & Spain & FD_01103 & $99.84(664 / 665)$ & GU250584 & $99.9(693 / 694)$ \\
\hline F. redolens & L96-13 & HQ731064 & Lebanon & FD_01101 & $99.84(663 / 664)$ & GU250581 & $99.7(701 / 703)$ \\
\hline
\end{tabular}


three nonpathogenic $F$. oxysporum isolates from chickpea showed two different IGS types; with isolates 90105 and 8250 from Spain sharing the same RFLP-IGS III type and isolate 506 from Italy being the only one representative of RFLP-IGS type IV (data not shown).

PCR assays using primers EF1 and EF2 yielded a TEF- $1 \alpha$ gene fragment of approximately $700 \mathrm{bp}$ from all Fusarium spp. isolates tested. Maximum parsimony analysis using 690 characters that included TEF- $1 \alpha$ sequences from the tested Fusarium isolates together with those from Baayen et al. (5), Jiménez-Gasco et al. (33), and Gurjar et al. (24) yielded a tree with a topology similar to that described by Baayen et al. (5) for the Fusarium spp. common to this latter study and the present one (Fig. 2). Nine of the Fusarium isolates in our study clustered with $N$. vasinfecta isolates within the $F$. solani complex (100\% bootstrap support). Fusarium sp. isolate 56.93 clustered ( $100 \%$ bootstrap support) with $F$. biseptatum and $F$. delphinoides, two species within the $F$. dimerum species group (57). Those 10 isolates and the different species above
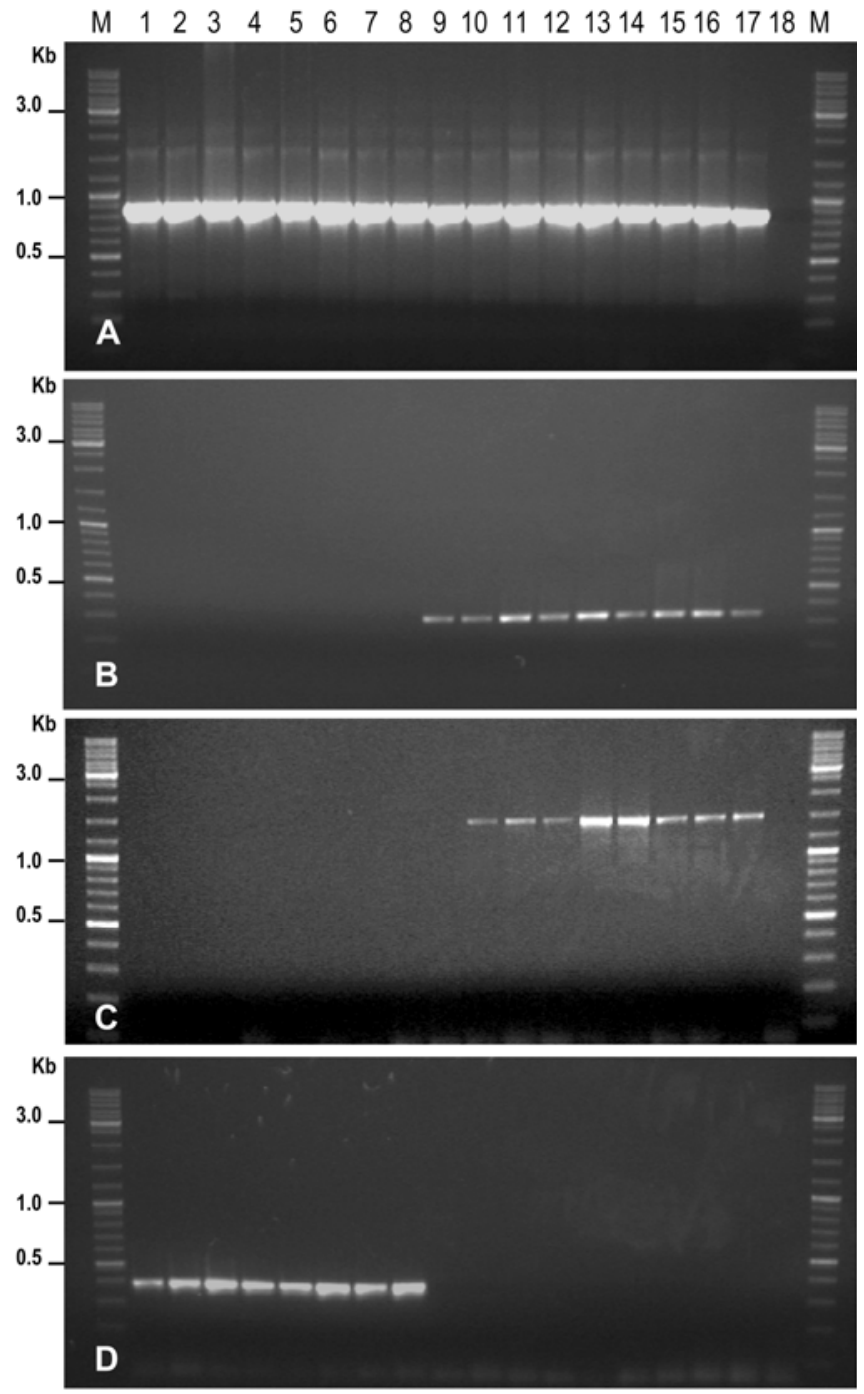

Fig. 1. Gel electrophoresis of DNA amplicons from polymerase chain reaction (PCR) assays using: A, primer set LR3 (64) and CS33 (60) that amplify a 900-bp region of the large subunit of the rRNA and was included as an internal positive control for successful PCR amplification; B, Fusarium oxysporum-specific primers FOF1 and FOR1 (30); C, F. oxysporum f. sp. ciceris-specific primers Foc0-12f and Foc0-12r (30); and D, F. redolens-specific primers Redolens-F and Redolens-R (9). Lane M, Gene-ruler DNA ladder mix (Fermentas, St. Leon-Rot, Germany); lanes 18, F. redolens isolates 9914I, 7982, 165-B1, 164-B3, 167-A2, 167-B, 181-2A, and L96-13, respectively; lane 9, F. oxysporum isolate 90105; lanes 9-17, F. oxysporum f. sp. ciceris isolates Foc-7802 (race 0), USA-1987-W17 (race 1B/C), 7989 (race 1A), 8605 (race 2), 8606 (race 3), 8607 (race 4), 8012 (race 5), and 8924 (race 6) , respectively; and lane 18, negative control (water). mentioned clustered independently (100\% bootstrap support) to the remaining Fusarium isolates included in the study. A well-supported $F$. hostae $-F$. redolens clade ( $79 \%$ bootstrap support) was resolved as a sister to the remaining ingroup taxa. All $F$. redolens isolates fell within a main clade, within which several subclades could be identified. In those subclades, all F. redolens isolates from chickpea in Morocco, Pakistan, and Spain clustered together, with the exception of isolate L96-13 from Lebanon that grouped in a different subclade. Of the remaining clades, the basal clade $(86 \%$ bootstrap) was the most phylogenetically diverse and included a $F$. nisikadoi-F. miscanthi clade ( $98 \%$ bootstrap), as well as the Gibberella fujikuroi and $F$. oxysporum complexes.

Several subclades could also be differentiated in the $F$. oxysporum complex. All $F$. oxysporum f. sp. ciceris isolates from our culture collection showed identical TEF-1 $\alpha$ sequence (33) and grouped within a subclade with $F$. oxysporum f. sp. ciceris isolates from India (24). Other chickpea $F$. oxysporum isolates referred to as nonpathogenic to chickpea and isolate NRRL-32158 from India (referred to as F. oxysporum f. sp. ciceris; 24 ) grouped with pathogenic $F$. oxysporum from other formae speciales in a different subclade. Finally, isolate 9009 from chickpea was included in the $G$. fujikuroi complex with another $F$. proliferatum isolate from chickpea in India (Fig. 2).

Pathogenic characterization of isolates on chickpea cultivars. All seven $F$. redolens isolates tested were pathogenic to the three chickpea cultivars in the study. Disease symptoms consisted of foliar yellowing and necrosis. Foliar yellowing developed at the stem base by 13 days after inoculation and progressed upward along the plant, with severely infected plants senescing prematurely. Leaflets first showed dull green discoloration that later turned yellowish, and they occasionally became necrotic and fell off by the end of the experiments. Examination of affected plants at the end of the experiment indicated that there was no discoloration in the vascular tissues. However, these plants showed 2- to 5-mmlong brown, necrotic lesions in their tap root, necrosis of lateral roots, and, occasionally, collar stem necrosis. Conversely, infection by race 0 isolate Foc-7802 of F. oxysporum f. sp. ciceris induced progressive foliar yellowing with vascular discoloration but no symptoms in the root system and only on P-2245. For this latter combination, disease reaction was more severe (i.e., shorter DO

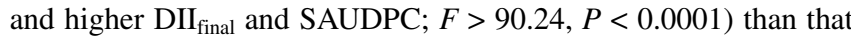
caused by any of the seven tested $F$. redolens isolates. Isolations from affected plants indicated that isolates of $F$. redolens grew within the cortex along the plant stem to a variable extent. Conversely, $F$. oxysporum f. sp. ciceris race 0 caused vascular infections and colonized the plant stem to a larger extent $(F>90.24, P$ $<0.0001)$ compared with that by $F$. redolens isolates. There were no significant differences $(F=2.97, P=0.0946)$ in the extent of root colonization by isolates of the two fungal species. A maximum $100 \%$ disease incidence occurred in all $F$. redolens isolatechickpea cultivar combinations, except for isolate 7982 in P-2245 and PV-61 that reached 95 and $75 \%$ disease incidence, respectively, and isolates L96-13 and 9914I that caused 95 and 85\% disease incidence, respectively, on PV-61 (Fig. 3A). Larger differences were observed for the other disease progress curve elements and plant colonization estimates used to characterize disease reaction (Figs. 3-5).

Overall, differences in disease progression and the extent of chickpea root and stem colonization were related primarily to $F$. redolens isolate and chickpea cultivar and, to a lesser extent, to their interaction (Figs. 3-5; Table 3). Thus, MANOVA analysis using disease progress curve elements (DO, DII $_{\text {final }}$, and SAUDPC) and variables associated with plant infection (root and stem colonization) revealed a significant effect of $F$. redolens isolates (Wilks' $\lambda$ $=0.1431, P<0.0001$ ), chickpea genotypes (Wilks' $\lambda=0.2036, P<$ 0.0001 ), and the interaction between these two factors (Wilks' $\lambda=$ $0.2987, P=0.0003$ ) (Table 3). Eigenvectors of characteristic roots in MANOVA analysis indicated that DII final $_{\text {and SAUDPC were the }}$ dependent variables with the greatest influence, while extent of root and stem colonization showed intermediate weights and DO 


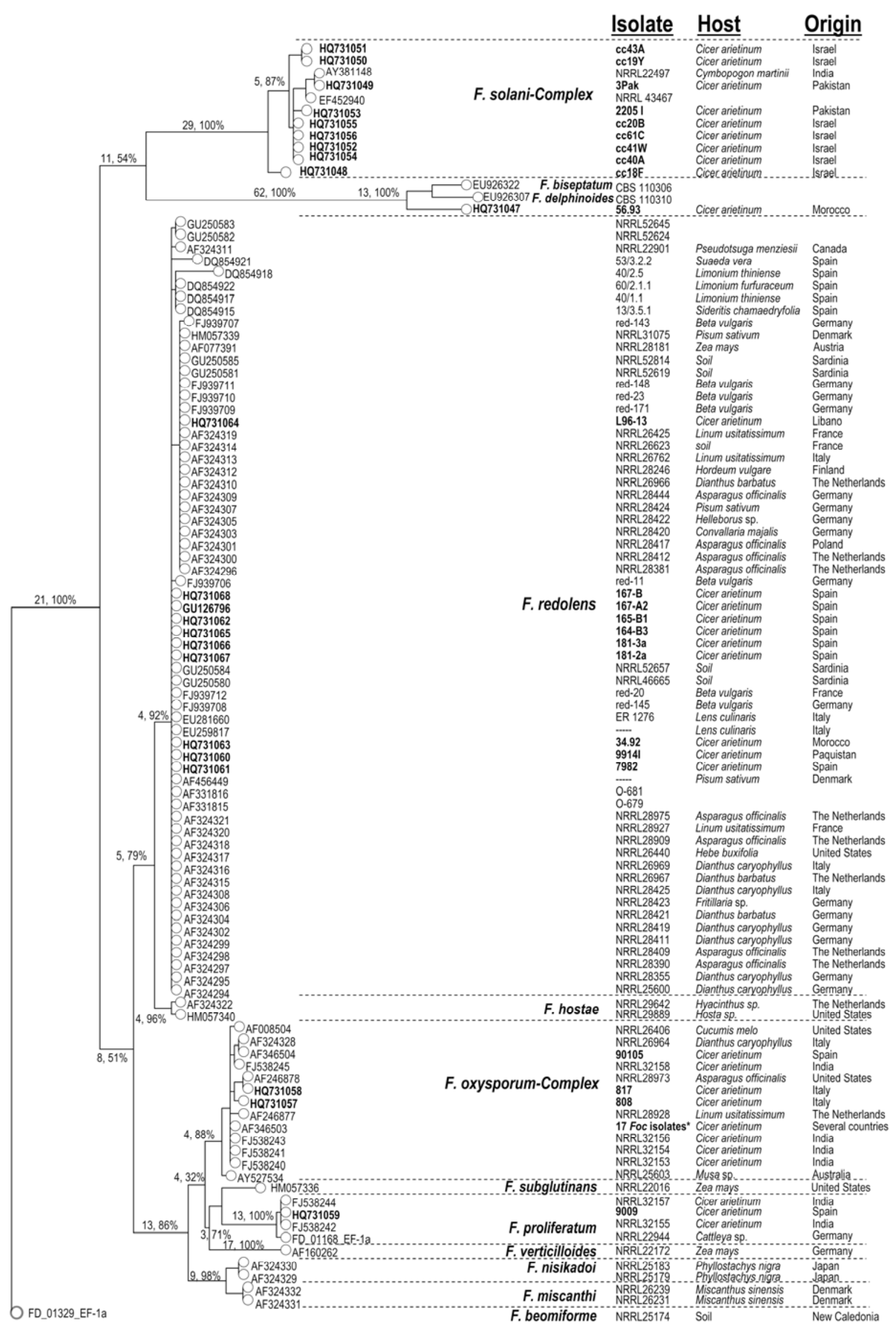

Fig. 2. Maximum parsimony phylogram inferred from the translation elongation factor-1 $\alpha$ sequences of Fusarium redolens, F. oxysporum, F. oxysporum f. sp. ciceris, and other Fusarium spp. isolates from chickpea derived from this study (in bold) as well as 23 GenBank accession sequences. A sequence of $F$. beomiforme (FUSARIUM-ID database accession FD_01329) was used to root the tree by the outgroup method. Brach length and bootstrap values $>50 \%$ from 1,000 maximum parsimony replications implemented in Bionumerics 6.1 are indicated in the branches. 
had the lowest weights (data not shown). Similarly to MANOVA, overall, F. redolens isolates and chickpea genotypes accounted for a larger amount of the variation explained by the ANOVA model (38.8 and $37.1 \%$, respectively) compared with that accounted for their interaction $(24.0 \%)$ (Table 3$)$.
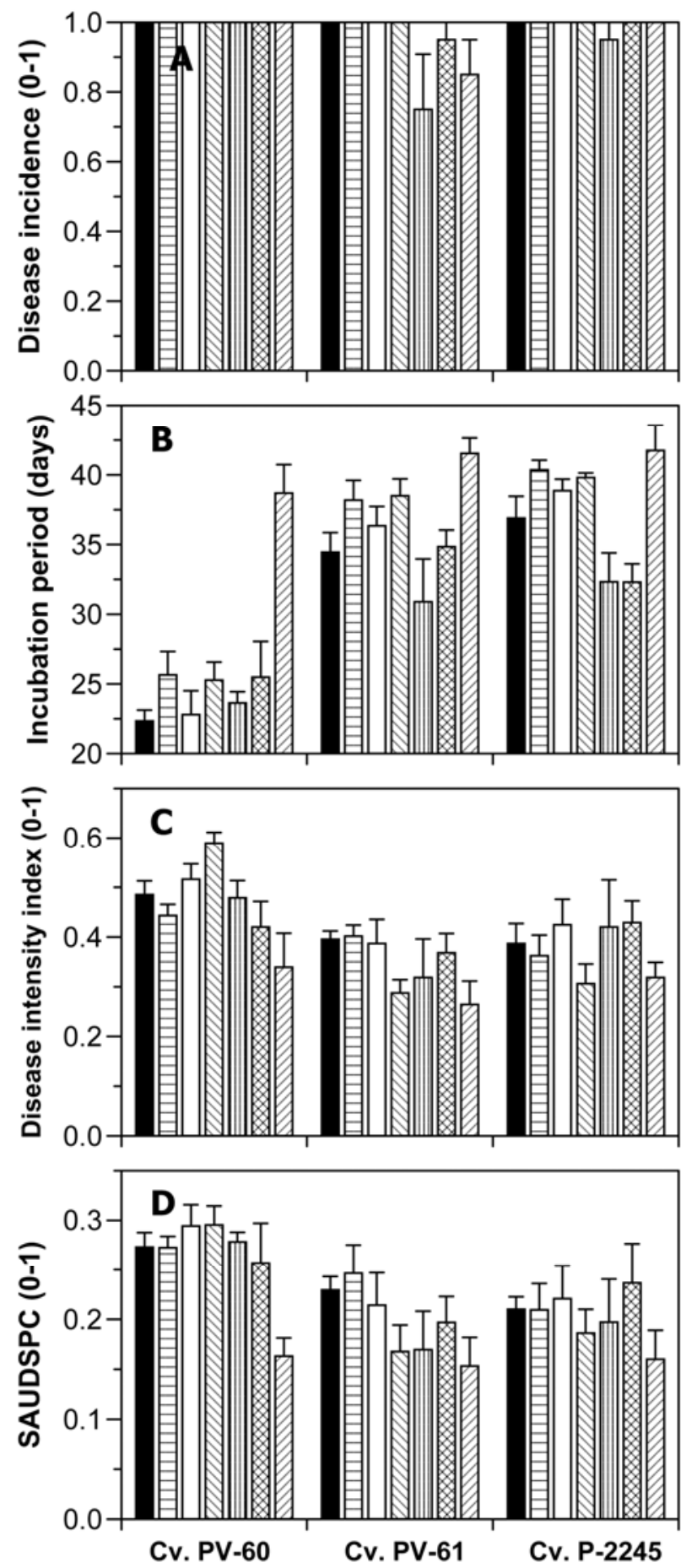

Isolates

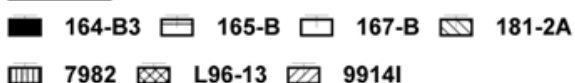

Fig. 3. Reaction of chickpea cultivars ('PV-60', 'PV-61', and 'P-2245') grown in soil artificially infested with seven Fusarium redolens isolates based on $\mathbf{A}$, disease incidence; B, disease onset (number of days until disease intensity index $>0$ ); $\mathbf{C}$, disease intensity index on the last day of assessment; and D, SAUDPC = area under disease progress curve standardized by duration time in days of the epidemic. Each bar is the mean of five replicated pots with four plants per pot. Error bars indicate the standard error of the mean.
Time to DO was lower on chickpea PV-60 regardless of F. redolens isolates, except for isolate 9914I that showed the longest DO in all three chickpea cultivars. The time to appearance of first symptom by isolate $9914 \mathrm{I}$ was estimated to be $38.7 \pm 2.03$ days on PV-60, 41.6 \pm 1.10 days on PV-61, and $41.8 \pm 1.80$ days on P-2245 (Figs. 3B and 4). In the remaining $F$. redolens isolate-chickpea cultivar combinations, time to DO ranged from 22.4 to 25.5 days on PV-60 and from 30.9 to 39.8 days on PV-61 and P-2245 (Fig. 3B).

Disease intensity, estimated by the DII final and SAUDPC, was determined primarily by the chickpea cultivar $(F>12.03, P<$ $0.0001)$ and, to a lesser extent, by pathogen isolate $(F>2.61, P<$ $0.0226)$, with no significant interaction $(F<1.53, P>0.1339)$ (Table 3 ). Thus, regardless of the $F$. redolens isolate, both $\mathrm{DII}_{\text {final }}$ and SAUDPC were significantly higher $(P<0.05)$ on chickpea PV60 and decreased in PV-61 and P-2245, which showed no significant differences $(P \geq 0.05)$ between them (Table 3; Figs. 3C and D

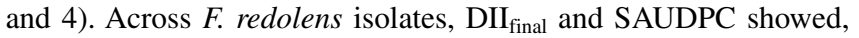
in general, a narrow range of variation for the different isolates, which was estimated at 0.39 to 0.44 and 0.22 to 0.24 , respectively, with the exception of isolate 9914I that reached much lower $(P<$ 0.05) DII final and SAUDPC values (Figs. 3C and D and 4).
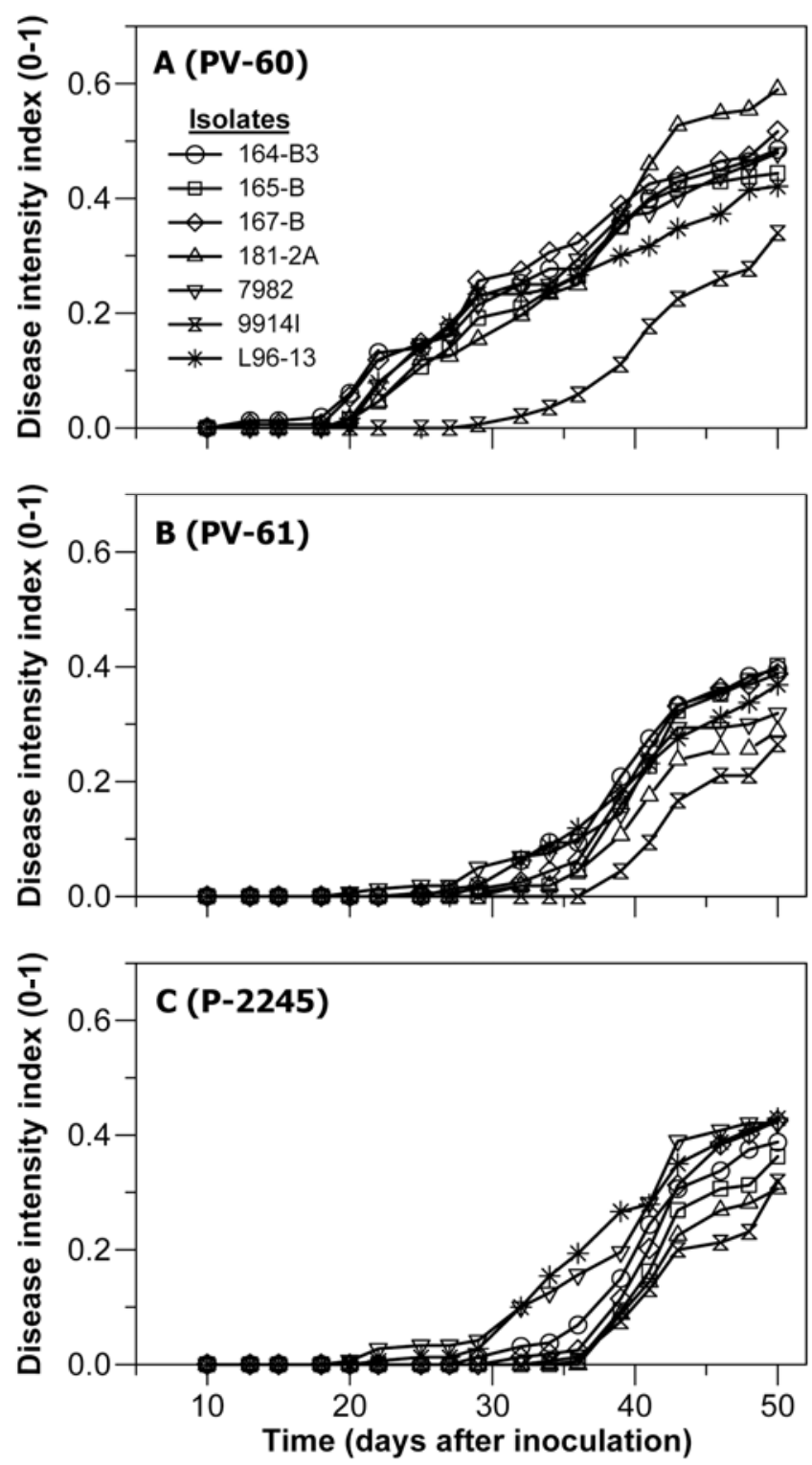

Fig. 4. Disease progress curves in three chickpea cultivars A, 'PV-60'; B, 'PV-61'; and C, 'P2245' grown in soil artificially infested with different Fusarium redolens isolates. Each point represents the mean disease intensity index of 20 plants (4 plants in each of five replicated pots). 
The extent of root colonization was determined mainly by the $F$. redolens isolate $(F=19.11, P<0.0001$; Table 3$)$. Overall, isolates 164-B3, 165-B, 167-B, 181-2A, and 9914I colonized chickpea roots of all three cultivars extensively, ranging from 3.20 to 3.50 $\mathrm{cm}$, but the extent of colonization was lower for isolates L96-14 $(2.66$ to $3.12 \mathrm{~cm})$ and $7982(1.18$ to $2.55 \mathrm{~cm})$ (Fig. 5). In contrast, the extent of stem colonization was determined mainly by chickpea cultivar $(F=11.40, P<0.0001$; Table 3$)$. Overall, the stem was colonized to a larger extent in P-2245 and PV-60 than in PV-61 ( $P$ $<0.05$; Fig. 5). Isolate 181-2A colonized the stem more extensively $(P<0.05)$ in PV-60 $(5.90 \pm 0.28 \mathrm{~cm})$ and PV-61 $(5.45 \pm 0.61 \mathrm{~cm})$ while isolate 7982 showed the highest $(6.63 \pm 0.57 \mathrm{~cm})$ and lowest $(2.78 \pm 0.63 \mathrm{~cm})$ level of colonization $(P<0.05)$ in $\mathrm{P}-2245$ and $\mathrm{PV}-61$, respectively. The remaining five $F$. redolens isolates showed

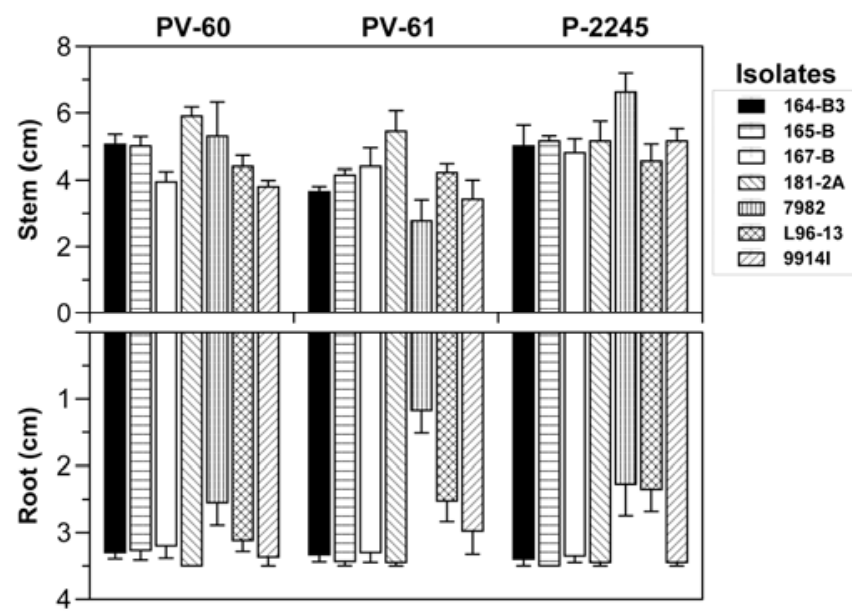

Fig. 5. Extent of stem (upper panel) and root (lower panel) colonization of three chickpea cultivars ('PV-60', 'PV-61', and 'P-2245') grown in soil infested with seven Fusarium redolens isolates. Each bar is the mean of 20 plants (4 plants in each of five replicated pots). Error bars indicate the standard error of the mean. intermediate colonization levels, though close within cultivars $(P \geq$ 0.05; Fig. 5).

Grouping $F$. redolens isolates by their geographic origin indicated that isolate L96-13 from Lebanon and isolates from southern Spain (164-B3, 165-B, 167-B, 181-2A, and 7982) did not differ $(F$ $<3.51, P>0.2815)$ in any of the disease progress curve and plant colonization associated variables, except for a significantly lower extent of root colonization $(F=11.65, P=0.0020)$ and DO $(F=$ $12.84, P=0.0013)$ by isolate L96-13, although only on P-2245 (Table 3; Figs. 3 and 5). In contrast, infection by isolate 9914I from Pakistan was associated with a significant delay of symptoms in all three cultivars $(F>7.56, P<0.0103)$ compared with the set of Spanish isolates above, and a lower disease intensity $(F>13.92, P$ $<0.0009)$ and stem colonization $(F=5.86, P=0.0222)$ on PV-60 only (Table 3; Figs. 3 and 5). Within the group of isolates from Spain, those originating in Córdoba province (central-west Andalusia) were as virulent as isolate 181-2A originating in Granada province (southeast Andalusia), except for a significantly higher $\mathrm{DII}_{\text {final }}(F=5.88, P=0.0220)$ in PV-60 and higher extent of stem and root colonization $(F>4.22, P<0.0492)$ in PV-60 and PV-61 by the latter (Table 3; Figs. 3 and 5).

To summarize the effects of main experimental factors and their interactions on disease reaction, additional multivariate analysis of principal components (PCs) was conducted. In this analysis, the first two PCs accounted for $82.1 \%$ of the total variance and are presented in Figure 6. As a result, the dimensionality of the three curve elements and two plant colonization variables was effectively reduced to two descriptive variables, $\mathrm{PC} 1$ and PC2. PC1 accounted for $55.7 \%$ of the variation and was dominated by high negative weights $(-0.88)$ for DO and high positive weights $(>0.96)$ for DII $_{\text {final }}$ and SAUDPC and, therefore, represents the position of disease reaction development over time and the amount of disease developed. PC2 accounted for $36.4 \%$ of the variation and was dominated by high positive weighs $(>0.66)$ for the extent of root and stem colonization by the pathogen (Fig. 5). According to position of disease reactions projected on the X (PC1)-Y (PC2) plane in Figure 6, symptoms were delayed from right to left and the over-

Table 3. Effects of infection by Fusarium redolens isolate, chickpea cultivar, and their interactions on disease progress curve elements on disease development and extent of plant colonization

\begin{tabular}{|c|c|c|c|c|c|c|c|c|c|c|c|c|}
\hline \multirow[b]{3}{*}{ Source of variation ${ }^{d}$} & & & \multicolumn{6}{|c|}{ Disease progress curve elements ${ }^{a}$} & \multicolumn{4}{|c|}{ Plant colonization $^{b}$} \\
\hline & \multicolumn{2}{|c|}{ MANOVA $^{c}$} & \multicolumn{2}{|c|}{ DO } & \multicolumn{2}{|c|}{ DII $_{\text {final }}$} & \multicolumn{2}{|c|}{ SAUDPC } & \multicolumn{2}{|c|}{ Root } & \multicolumn{2}{|c|}{ Stem } \\
\hline & Wilks' $\lambda$ & $P>F$ & $\boldsymbol{F}$ & $P>F$ & $\boldsymbol{F}$ & $P>F$ & $\boldsymbol{F}$ & $P>F$ & $\boldsymbol{F}$ & $P>F$ & $\boldsymbol{F}$ & $P>F$ \\
\hline Isolate & 0.1431 & $<0.0001$ & 17.79 & $<0.0001$ & 2.62 & 0.0225 & 3.51 & 0.0038 & 19.11 & $<0.0001$ & 2.72 & 0.0184 \\
\hline Cultivar & 0.2036 & $<0.0001$ & 109.09 & $<0.0001$ & 13.20 & $<0.0001$ & 12.04 & $<0.0001$ & 3.79 & 0.0265 & 11.40 & $<0.0001$ \\
\hline Isolate $\times$ cultivar & 0.2987 & 0.0003 & 2.98 & 0.0017 & 1.52 & 0.1340 & 0.86 & 0.5860 & 2.23 & 0.0171 & 2.51 & 0.0073 \\
\hline \multicolumn{13}{|l|}{$\begin{array}{l}\text { Contrasts } \\
\text { PV-60 }\end{array}$} \\
\hline Spain vs. L96-13 & 0.8393 & 0.4855 & 0.74 & 0.3962 & 3.51 & 0.0713 & 1.21 & 0.2815 & 0.06 & 0.8135 & 1.56 & 0.2218 \\
\hline Spain vs. 9914I & 0.2734 & $<0.0001$ & 66.48 & $<0.0001$ & 13.92 & 0.0009 & 25.96 & $<0.0001$ & 1.08 & 0.3082 & 5.86 & 0.0222 \\
\hline $\begin{array}{l}\text { Spain: Co vs. Gr } \\
\text { PV-61 }\end{array}$ & 0.5982 & 0.0229 & 0.81 & 0.3771 & 5.88 & 0.0220 & 0.45 & 0.5078 & 4.43 & 0.0444 & 4.23 & 0.0491 \\
\hline Spain vs. L96-13 & 0.8227 & 0.4201 & 0.21 & 0.6534 & 0.05 & 0.8303 & 0.07 & 0.7894 & 2.68 & 0.1125 & 0.08 & 0.7851 \\
\hline Spain vs. 9914I & 0.6694 & 0.0697 & 10.40 & 0.0032 & 3.79 & 0.0616 & 2.79 & 0.1059 & 0.02 & 0.8855 & 1.68 & 0.2049 \\
\hline $\begin{array}{l}\text { Spain: Co vs. Gr } \\
\text { P2245 }\end{array}$ & 0.3937 & 0.0003 & 3.61 & 0.0679 & 3.25 & 0.0824 & 2.17 & 0.1517 & 6.17 & 0.0192 & 10.81 & 0.0027 \\
\hline Spain vs. L96-13 & 0.4494 & 0.0011 & 12.84 & 0.0013 & 0.72 & 0.4049 & 0.88 & 0.3562 & 11.65 & 0.0020 & 2.21 & 0.1481 \\
\hline Spain vs. 9914I & 0.6763 & 0.0770 & 7.56 & 0.0103 & 1.14 & 0.2939 & 1.73 & 0.1994 & 1.06 & 0.3118 & 0.13 & 0.7180 \\
\hline Spain: Co vs. Gr & 0.6941 & 0.0983 & 3.12 & 0.0880 & 2.48 & 0.1263 & 0.45 & 0.5079 & 1.59 & 0.2175 & 0.20 & 0.6584 \\
\hline
\end{tabular}

${ }^{a}$ Disease intensity index (DII) was calculated based on the incidence and severity of symptoms recorded at 2- to 3-day intervals. Disease onset (DO) was estimated as the number of days to initial symptoms; DII $_{\text {final }}=$ disease intensity index at the final date of disease assessment and SAUDPC $=$ area under disease intensity progress curve estimated by the trapezoidal integration method and standardized for the epidemic duration. Data are the means of five replicated pots, each with four plants.

${ }^{b}$ Inoculated plants were incubated for 50 days in a growth chamber. To determine the occurrence of plant infection, isolations were made from all plants showing a severity score $\leq 4$ within a 0 -to- 4 rating scale, from four stem internodes starting from the hypocotyl, and from the main root (four segments).

${ }^{c}$ Wilks' $\lambda$ statistic and associated probability $(P)$ for the hypothesis of overall $F$. redolens and chickpea cultivar effects after multivariate analysis of variance (MANOVA).

${ }^{\mathrm{d}}$ Linear single-degree-of-freedom contrasts computed to test the effect of selected treatment combinations at a significance level of $P<0.05$. Contrast $=$ contrasts by isolate within cultivars: F. redolens isolates were grouped according to their geographic origin; Spain = isolates 164-B3, 165-B, 167-B, 1812A, and 7982; Co = Córdoba, isolates 164-B3, 165-B, 167-B, and 7982; Gr = Granada, isolate 181-2A. 
all disease intensity increased along the $x$-axis. Similarly, the extent of plant colonization increased from bottom to top along the $y$-axis. Overall, disease reactions were located according to chickpea cultivars; hence, reactions developed on PV-61 and P-2245 were located at the left side and in the middle part while those developed on PV-60 were located at the right side (Fig. 6). Within each cultivar, lower differences occurred among $F$. redolens isolates. Isolate 9914I induced the most delayed reaction and lowest disease inten-

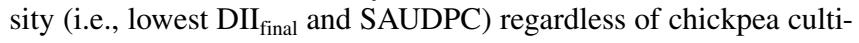
var, with colonization level increasing in PV61, PV-60, and P2245 , in that order. Isolates 181-2A and 9914I induced reactions of similar disease intensity and plant colonization levels in smallseeded PV-61 and P-2245. Conversely, isolate 181-2A induced the most severe disease reaction (i.e., lowest DO and highest $\mathrm{DII}_{\text {final }}$ and SAUDPC) and extent of colonization in PV-60. Isolates 164-B, $165-B$, and 167-B induced reactions of intermediate disease intensity in PV-61 and P-2245 but the extent of colonization was larger in P-2245. Finally, all remaining $F$. redolens isolates, except for isolate 9914I, caused a severe disease reaction in PV-60, which was associated with moderate (167-B, 7982, and L96-13) or high (164-B, 165-B, and 181-2A) extent of colonization of the plant (Fig. 6).

\section{Discussion}

Use of morphological traits for differentiating among morphologically similar Fusarium spp., such as F. oxysporum and $F$. redolens, may lead to the wrong pathogen identification. However, accurate identification of pathogenic Fusarium spp. and $F$. oxysporum formae speciales is crucial for the efficient management of Fusarium diseases, particularly if resistant cultivars are one of the few and most effective control measures, as exemplified by Fusarium wilt of chickpea $(28,39,40)$. In this study, use of previously developed specific-PCR protocols $(9,31,32)$ and pathogenicity assays demonstrated for the first time that $F$. redolens is pathogenic on chickpea, causing root necrosis and acropetal foliar yellowing. Furthermore, these PCR protocols allowed the exact and quick differentiation among $F$. oxysporum sensu lato, $F$. redolens, and $F$. oxysporum f. sp. ciceris isolated from chickpea showing a wilt-like symptom. We demonstrated that isolating $F$. oxysporum-like Fusarium spp. from chickpea showing wilting-like symptoms, even if performed from upper stem tissues, does not necessarily guarantee recovery of $F$. oxysporum f. sp. ciceris and can lead to misidentification if the fungal isolates are not further characterized.

Indeed, by using the specific-PCR protocols mentioned above and sequencing of the TEF- $1 \alpha$ gene, we showed that several isolates of Fusarium spp. provided by scientists around the world had

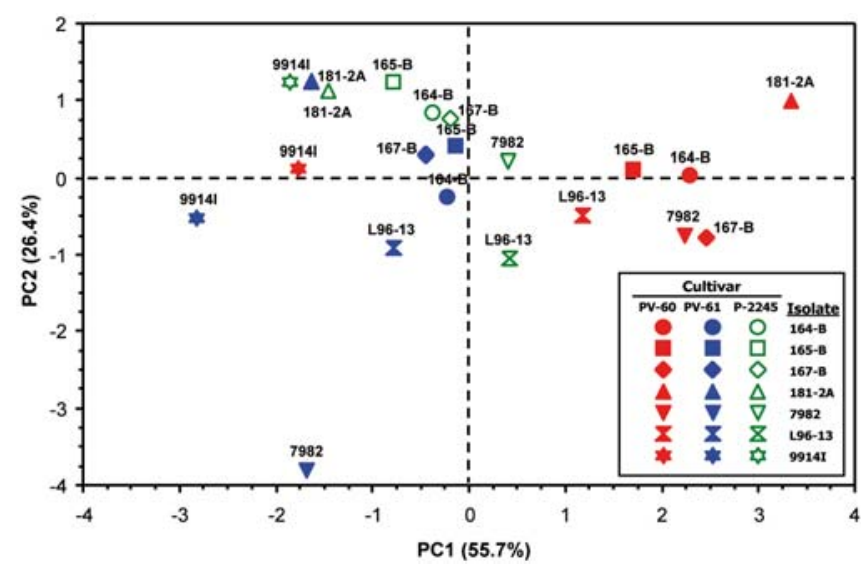

Fig. 6. Projection of factor scores on the plane of principal component (PCs) 1 and 2 from PC analysis for disease developed on three chickpea cultivars ('PV-60', 'PV61', and ' $\mathrm{P}-2245$ ') grown in soil infested with seven isolates of Fusarium redolens. Disease intensity (PC1) increased along the $x$-axis (most disease on right) and plant colonization (PC2) on the $y$-axis was most extensive at the top. originally been miss-assigned to the forma specialis ciceris by the source laboratory. Those isolates consistently failed to amplify a $F$. oxysporum f. sp. ciceris-specific marker (32) but were identified as $F$. redolens, $F$. oxysporum-complex, $F$. solani-complex, $F$. proliferatum, $N$. vasinfecta, or unknown Fusarium sp. Such misidentification could be attributed to different circumstances. (i) Isolations in pure culture from Fusarium-wilt-affected chickpea does not necessarily result in $F$. oxysporum f. sp. ciceris but often yielded nonpathogenic isolates of $F$. oxysporum or other saprophytic Fusarium spp. with morphology similar to that of the $F$. oxysporum species-complex (36,59; R. M. Jiménez-Díaz and B. B. Landa, unpublished results). Without further characterization, this may have led to storage of isolates wrongly assumed as $F$. oxysporum f. sp. ciceris because of their association with wilting symptoms. (ii) Lack of extensive experience in the identification of Fusarium spp. may have led to overlooking morphological features and microscopic traits key for differentiating morphologically close species. (iii) Storage of bulk isolates while disregarding the need of single-sporing cultures before storage can result in storing a mixture of hidden species. Finally, (iv) eventual contamination of single-spore cultures during storage of isolates which remain undetected if they are not checked further. All these facts stress the need for carefully assuring that a Fusarium sp. isolate induces exactly the same vascular infection and disease symptoms on race differentials compared with a previously described $F$. oxysporum f. sp. ciceris race. As an example, the previously described race 3 of the Fusarium wilt pathogen was recently and erroneously redescribed as $F$. proliferatum (24).

In this present study, the newly reported symptomatic infection of chickpea showing wilting-like symptoms in Spain by F. redolens was demonstrated to occur also in other chickpea-producing countries, including Lebanon, Morocco, and Pakistan. Here, we demonstrated that $F$. redolens isolates were previously misdiagnosed as $F$. oxysporum f. sp. ciceris, and characterized them molecularly by means of different molecular protocols. Indeed, use of these protocols in our laboratory has facilitated proper identification of chickpea Fusarium isolates and helped to sort out some isolates originally miss-assigned to a wrong species, as happened for isolate 7982 , originally assigned to the yellowing pathotype of $F$. oxysporum f. sp. ciceris. The differentiation between $F$. redolens and F. oxysporum f. sp. ciceris was further strengthened by their distinct IGS type in RFLP analysis with seven restriction enzymes, which also showed that all $F$. oxysporum f. sp. ciceris isolates representative of the eight described pathogenic races have identical RFLP-IGS restriction patterns regardless of their geographic origin or race. It should be emphasized that all $F$. oxysporum f. sp. ciceris isolates used in this study and additional ones from other studies, including race 3 isolates, share an identical sequence of the ITS region of rDNA (D. J. Fernández and B. B. Landa, unpublished data ) and a $1.5-\mathrm{kb}$ sequence-characterized amplified regionspecific sequence of the forma specialis ciceris (GenBank accession AF492451; 32), which supports the hypothesis that each of those eight races forms a monophyletic lineage (33) and that race 3 of the Fusarium wilting pathogen on chickpea should be named $F$. oxysporum f. sp. ciceris and not $F$. proliferatum, as was erroneously claimed (24).

A similar scenario of misidentifications of $F$. redolens isolates has been described for other formae speciales of $F$. oxysporum, including f. sp. dianthi (9), f. sp. lini (5), and f. sp. hebae (5). Particularly interesting is the situation of $F$. oxysporum f. sp. dianthi and $F$. redolens f. sp. dianthi, for which classification of vegetative compatibility groups (VCGs) and races of carnation isolates of $F$. oxysporum sensu lato has been hampered in the past by controversies concerning the distinction of $F$. redolens from $F$. oxysporum $(2,21,50)$. Thus, Baayen and Kleijn (3) originally described five VCGs among isolates belonging to $F$. oxysporum $\mathrm{f}$. sp. dianthi but two of them were recently demonstrated to be $F$. redolens $\mathrm{f}$. sp. dianthi (7).

In addition to distinctiveness between $F$. redolens and $F$. oxysporum indicated by specific-PCR and RFLP-IGS assays, results 
from phylogenetic analysis of the TEF- $1 \alpha$ gene sequence clearly indicate that $F$. redolens and $F$. oxysporum from chickpea lack a sister group relationship (Fig. 2). Previous phylogenetic analyses of sequences of TEF- $1 \alpha$, the nuclear ITS region and large subunit 28S rDNA, the mitochondrial small subunit rDNA, and $\beta$-tubulin have also showed that the $F$. oxysporum complex, the $G$. fujikuroi complex, and the F. miscanthi-F. nisikadoi clade form a monophyletic group independent from the $F$. redolens $-F$. hostae clade $(2,17,19,52,53,61,62)$. As for the $F$. oxysporum complex, $F$. redolens forms a species complex that includes isolates from different hosts and countries bearing the ability to cause several diseases on different crops $(10,20,21)$. Thus, host specificity in some $F$. redolens isolates has led to grouping them into formae speciales as was done in the $F$. oxysporum complex; that is, $F$. redolens $\mathrm{f}$. sp. dianthi Gerlach (20), F. redolens f. sp. spinaciae (Sherb.) Subram. (58), and $F$. redolens f. sp. asparagi Baayen (6). It would be worthwhile developing further pathogenicity tests with $F$. redolens isolates from chickpea on other plant species to determine whether or not they show pathogenic specificity on this legume.

In the phylogenetic analysis of TEF- $1 \alpha$ in our study, the grouping of $F$. redolens isolates within a subclade was not correlated with their geographic origin or host source. This is in agreement with other studies where host preference in F. redolens grouped into formae speciales did not appear to correlate with subclades resolved by the molecular phylogeny, which may indicate that members of those $F$. redolens formae speciales may have independent evolutionary origins (5). In our study, all F. redolens isolates from chickpea from three different countries showed a low genetic diversity in TEF-1 $\alpha$ sequence and grouped together in one subclade, with the exception of isolate L96-13 from Lebanon. This clustering could support the hypothesis that pathogenicity to chickpea has developed recently in F. redolens (i.e., the host plant has not yet developed specific resistance against the pathogen and the latter has not needed to evolve).

F. redolens has been referred as an important pathogen on different crops, including asparagus $(65)$, carnation $(7,44)$, pelargonium (55), rose (66), and tomato (25); and as a weak pathogen on spinach (41) and some legumes. F. redolens has been referred as a pathogen causing foot rot on pea and bean (12), necrotic taproot lesions and lateral root necrosis on soybean (8), and wilt and root rot on lentil (56); however, to our knowledge, pathogenicity to chickpea has not been reported yet. In this present study, we report differences in virulence among seven chickpea $F$. redolens isolates from three countries on three chickpea cultivars (P-2245, PV-60, and PV-61) commonly grown in Spain. All tested F. redolens isolates induced disease symptoms similar to those reported before for the yellowing-inducing isolates of $F$. oxysporum f. sp. ciceris $(27,29)$ but in the absence of vascular infection characteristic of the latter. Symptoms induced by $F$. redolens include foliar yellowing that started 13 days after inoculation and gradually progressed upward on the plants, which was associated with cortical collar and lateral root necrosis. Interestingly, similar symptoms were described by Trapero-Casas and Jiménez-Díaz (59) in chickpea inoculated with what they named reddish-colony-forming $F$. oxysporum isolated from chickpea plants affected by the 'Seca' disease complex in southern Spain. With such a name, those authors aimed to distinguish the reddish $F$. oxysporum isolates from the typical salmon-cream-colored colonies of vascular-infecting $F$. oxysporum f. sp. ciceris isolates. We noted that some of the $F$. redolens from Spain in this study formed reddish-colored colonies (data not shown), which could imply that isolates that TraperoCasas and Jiménez-Díaz (59) characterized as F. oxysporum using only morphology-based diagnoses could actually be F. redolens. As reported by Trapero-Casas and Jiménez-Díaz (59) for reddish $F$. oxysporum isolates, F. redolens isolates in our study induced extensive foliar yellowing but failed to cause death of inoculated plants. The opposite has been observed for the yellowing-inducing isolate Foc-7802 of F. oxysporum f. sp. ciceris which killed all plants by 50 days after inoculation. All these considerations would suggest that $F$. redolens is a weak pathogen on chickpea, substantiating the conclusion drawn by Trapero-Casas and Jiménez-Díaz (59) in their work about reddish $F$. oxysporum isolates. Although $F$. redolens has been usually referred to as a weak pathogen on different pulses, including pea, bean, and soybean $(8,12)$, it has been recently described as a highly virulent on lentil (56).

Finally, because several pathogenic forms of $F$. oxysporum and $F$. redolens may cause similar symptoms on a host plant, as has been shown on several crops (for example, asparagus [6,65], broad bean and pea [10], carnation [21], lentil [56], and spinach [41]) and chickpea (this study), our results emphasize the importance of assuring the accurate identification and distinction between these two species in a geographical area for which suitable molecular protocols are available. This approach would facilitate the development of resistant germplasm for these crops, if available, and better the understanding of the etiology and epidemiology of the diseases caused by the different formae speciales of $F$. oxysporum and F. redolens.

\section{Acknowledgments}

Financial support for this research was provided by grants AGL2004-01231 from 'Ministerio de Educación y Ciencia' of Spain and the European Social Fund, AGR580 from 'Consejería de Economía, Innovación y Ciencia', Junta de Andalucía, and an 'Intramural Project' to B. B. Landa from the Spanish National Research Council (CSIC). We thank G. Contreras-Arias and F. J. Durán (IASCSIC) for their excellent technical assistance.

\section{Literature Cited}

1. Alves-Santos, F. M., Benito, E. P., Eslava, A. P., and Díaz-Mínguez, J. M. 1999. Genetic diversity of Fusarium oxysporum strains from common bean fields in Spain. Appl. Environ. Microbiol. 65:3335-3340.

2. Baayen, R. P., and Gams, W. 1988. The elegans fusaria causing wilt disease of carnation. I. Taxonomy. Neth. J. Plant Pathol. 94:273-278.

3. Baayen, R. P., and Kleijn, J. 1989. The elegans fusaria causing wilt disease of carnation. II. Distinction of vegetative compatibility groups. Neth. J. Plant Pathol. 95:185-194.

4. Baayen, R. P., O’Donnell, K., Bonants, P. J. M., Cigelnik, E, Kroon, L. P. N M., Roebroeck, E. J. A., and Waalwijk, C. 2000. Gene genealogies and AFLP analyses in the Fusarium oxysporum complex identify monophyletic and non-monophyletic formae speciales causing wilt and rot diseases. Phytopathology 90:891-900.

5. Baayen, R. P., O'Donnell, K., Breeuwsma, S., Geiser, D. M., and Waalwijk, C. 2001. Molecular relationships of fungi within the Fusarium redolens- $F$ hostae clade. Phytopathology 91:1037-1044.

6. Baayen, R. P., Van den Boogert, P. H. J. F., Bonants, P. J. M., Poll, J. T. K. Blok, W. J., and Waalwijk, C. 2000. Fusarium redolens f. sp. asparagi, causal agent of asparagus root rot, crown rot and spear rot. Eur. J. Plant Pathol. 106:907-912.

7. Baayen, R. P., Van Dreven, F., Krijger, M. C., and Waalwijk, C. 1997. Genetic diversity in Fusarium oxysporum f. sp. dianthi and Fusarium redolens f. sp. dianthi. Eur. J. Plant Pathol. 103:395-408.

8. Bienapfl, J. C., Malvick, D. K., and Percich, J. A. 2010. First report of Fusarium redolens causing root rot of soybean in Minnesota. Plant Dis. 94:1069.

9. Bogale, M., Wingfield, B. D., Wingfield, M. J., and Steenkamp, E. T. 2007. Species-specific primers for Fusarium redolens and a PCR-RFLP technique to distinguish among three clades of Fusarium oxysporum. FEMS Microbiol. Lett. 271:27-32.

10. Booth, C. 1971. The Genus Fusarium. Commonwealth Mycological Institute, Kew, UK

11. Bouhot, D., and Rouxel, F. 1971. Technique selective et quantitative d'analyse des Fusarium oxysporum et Fusarium solani dans le sol. Mode d'emploi. Ann. Phytopathol. 3:251-254.

12. Clarkson, J. D. S.1978. Pathogenicity of Fusarium spp. associated with foot-rots of peas and beans. Plant Pathol. 27:110-117.

13. Edel, V., Steinberg, C., Avelange, I., Laguerre, G., and Alabouvette, C. 1995. Comparison of three molecular methods for the characterization of Fusarium oxysporum strains. Phytopathology 85:579-585.

14. Edel, V., Steinberg, C., Gautheron, N., and Alabouvette, C. 1997. Populations of nonpathogenic Fusarium oxysporum associated with roots of four plant species compared to soilborne populations. Phytopathology 87:693697.

15. Edel, V., Steinberg, C., Gautheron, N., and Alabouvette, C. 2000. Ribosomal DNA-targeted oligonucleotide probe and PCR assay specific for Fusarium oxysporum. Mycol. Res. 104:518-526.

16. Food and Agriculture Organization of the United Nations Statistical Database (FAOSTAT). 2010. FAOSTAT production statistics of crops. Online. http://faostat.fao.org/site/567/default.aspx\#ancor

17. Gams, W., Klamer, L., and O’Donnell, K. 1999. Fusarium miscanthi sp. nov. from Miscanthus litter. Mycologia 91:263-268.

18. Geiser, D. M., Jiménez-Gasco, M. M., Kang, S., Makalowska, I., Veer- 
araghavan, N., Ward, T. J., Zhang, N., Kuldau, G. A., and O’Donnell, K. 2004. FUSARIUM-ID v. 1.0: a DNA sequence database for identifying Fusarium. Eur. J. Plant Pathol. 110:473-479.

19. Geiser, D. M., Juba, J. H., Wang, B., and Jeffers, S. N. 2001. Fusarium hostae sp. nov., a relative of $F$. redolens with a Gibberella teleomorph. Mycologia 93:670-678.

20. Gerlach, W. 1961. Fusarium redolens Wr., seine Morphologie und systematische Stellung. Ein Beitrag zur Kenntnis der Elegans-Fusarien. Phytopathol. Z. 42:150-160.

21. Gerlach, W., and Pag, H. 1961. Fusarium redolens Wr., seine phytopathologische Bedeutung und eine an Dianthus-Arten gefäßparasitäre Form ( $F$. redolens Wr. f. dianthi Gerlach). Phytopathol. Z. 42:349-361.

22. Gordon, W. L. 1952. The occurrence of Fusarium species in Canada. II. Prevalence and taxonomy of Fusarium species in cereal seeds. Can. J. Bot. 30:236-238.

23. Grewal, J. S., Pal, M., and Kulshrestha, D. D. 1974. A new record of wilt of gram caused by Fusarium solani. Curr. Sci. 43:767.

24. Gurjar, G., Barve, M., Giri, A., and Gupta, V. 2009. Identification of Indian pathogenic races of Fusarium oxysporum f. sp. ciceris with gene specific, ITS and random markers. Mycologia 101:484-495.

25. Hamini-Kadar, N., Edel-Hermann, V., Gautheron, N., and Steinberg, C. 2010. First report of Fusarium commune and Fusarium redolens causing crown and root rot on tomato in Algeria. New Dis. Rep. 22:3.

26. Jalali, B. L., and Chand, H. 1992. Chickpea wilt. Pages 429-444 in: Plant Diseases of International Importance. Vol. I. Diseases of Cereals and Pulses. U. S. Singh, A. N. Mukhopadhayay, J. Kumar, and H. S. Chaube, eds. Prentice Hall, Englewood Cliffs, NJ.

27. Jiménez-Díaz, R. M., Basallote Ureba, M. J., and Rapoport, H. 1989. Colonization and pathogenesis in chickpea infected by races of Fusarium oxysporum f. sp. ciceri. Pages 113-121 in: Vascular Wilt Diseases of Plants. E. C. Tjamos and C. H., eds. NATO ASI Series, Vol. 28, Springer-Verlag, Berlin.

28. Jiménez-Díaz, R. M., Crinó, P., Halila, M. H., Mosconi, C., and TraperoCasas, A. 1993. Screening for resistance to Fusarium wilt and Ascochyta blight in chickpea. Pages 77-96 in: Breeding for Stress Tolerance in CoolSeason Food Legumes. K. B. Singh and M. C. Saxena, eds. John Wiley and Sons, Chichester, England.

29. Jiménez-Díaz, R. M., Jiménez-Gasco, M. M., Landa, B. B., Castillo, P., and Navas-Cortés, J. A. 2011. Fusarium wilt of chickpea. Pages 16-20 in: Compendium of Chickpea and Lentil Diseases and Pests. W. Chen, H. C. Sharma, and F. J. Muehlbauer, eds. American Phytopathological Society, St. Paul, MN.

30. Jiménez-Fernández, D., Montes-Borrego, M., Jiménez-Díaz, R. M., NavasCortés, J. A., and Landa, B. B. 2011. In planta and soil quantification of Fusarium oxysporum f. sp. ciceris and evaluation of Fusarium wilt resistance in chickpea with a newly developed quantitative PCR assay. Phytopathology 101:250-262.

31. Jiménez-Fernández, D., Montes-Borrego, M., Navas-Cortés, J. A., JiménezDíaz, R. M., and Landa, B. B. 2010. Identification and quantification of Fusarium oxysporum in planta and soil by means of an improved specific and quantitative PCR assay. Appl. Soil Ecol. 46:372-382.

32. Jiménez-Gasco, M. M., and Jiménez-Díaz, R. M. 2003. Development of a specific polymerase chain reaction based-assay for the identification of Fusarium oxysporum f. sp. ciceris and its pathogenic races 0, 1A, 5 and 6 . Phytopathology 93:200-209.

33. Jiménez-Gasco, M. M., Milgroom, M. G., and Jiménez-Díaz, R. M. 2002. Gene genealogies support Fusarium oxysporum f. sp. ciceris as a monophyletic group. Plant Pathol. 51:72-77.

34. Jiménez-Gasco, M. M., Pérez-Artés, E., and Jiménez-Díaz, R. M. 2001. Identification of pathogenic races $0,1 \mathrm{~B} / \mathrm{C}, 5$, and 6 of Fusarium oxysporum f. sp. ciceris with random amplified polymorphic DNA (RAPD). Eur. J. Plant Pathol. 107:237-248.

35. Kaiser, W. J., and Danesh, D. 1971. Etiology of virus-induced wilt of Cicer arietinum. Phytopathology 61:453-457.

36. Kaiser, W. J., Klein, R. E., Larsen, R. C., and Wyatt, S. D. 1993. Chickpea wilt incited by pea streak carlavirus. Plant Dis. 77:922-926.

37. Kraft, J. M. 1969. Chickpea, a new host of Fusarium solani f. sp. pisi. Plant Dis. Rep. 53:110-111

38. Landa, B. B., Montes-Borrego, M., Muñoz-Ledesma, F. J., and JiménezDíaz, R. M., 2007. Phylogenetic analysis of downy mildew pathogens of opium poppy and PCR-based in planta and seed detection of Peronospora arborescens. Phytopathology 97:1380-1390.

39. Landa, B. B., Navas-Cortés, J. A., and Jiménez-Díaz, R. M. 2004. Integrated management of Fusarium wilt of chickpea with sowing date, host resistance and biological control. Phytopathology 94:946-960.

40. Landa, B. B., Navas-Cortés, J. A., Jiménez-Gasco, M. M., Katan, J., Retig, B., and Jiménez-Díaz, R. M. 2006. Temperature response of chickpea cultivars to races of Fusarium oxysporum $\mathrm{f}$. sp. ciceris, causal agent of Fusarium wilt. Plant Dis. 90:365-374.
41. Larsson, M., and Olofsson, J. 1994. Prevalence and pathogenicity of spinach root pathogens of the genera Aphanomyces, Phytophthora, Fusarium Cylindrocarpon, and Rhizoctonia in Sweden. Plant Pathol. 43:251-260.

42. Leslie, J. F., Zeller, K. A., and Summerell, B. A. 2001. Icebergs and species in populations of Fusarium. Physiol. Mol. Plant Pathol. 59:107-117.

43. Madden, L. V., Hughes, G., and van den Bosch, F. 2007. The Study of Plant Disease Epidemics. American Phytopathological Society, St. Paul, MN.

44. Migheli, Q., Briatore, E., and Garibaldi, A. 1998. Use of random amplified polymorphic DNA (RAPD) to identify races 1, 2, 4 and 8 of Fusarium oxysporum f. sp. dianthi in Italy. Eur. J. Plant Pathol. 104:49-57.

45. Ministerio de Medio Ambiente y Medio Rural y Marino. 2010. Anuario de Estadística. 13. Superficies y producciones de cultivos. Online. http://www.mapa.es/es/estadistica/pags/anuario/2009/indice.asp

46. Mishra, P. K., Fox, R. T. V., and Culham, A. 2003. Development of a PCRbased assay for rapid and reliable identification of pathogenic Fusaria FEMS Microbiol. Lett. 213:329-332.

47. Navas-Cortés, J. A., Hau, B., and Jiménez-Díaz, R. M. 2000. Yield loss in chickpeas in relation to development of Fusarium wilt epidemics. Phytopathology 90:1269-1278.

48. Navas-Cortés, J. A., Landa, B. B., Méndez-Rodríguez, M. A., and JiménezDíaz, R. M. 2007. Quantitative modeling of the effects of temperature and inoculum density of Fusarium oxysporum $\mathrm{f}$. sp. ciceris races 0 and 5 on the development of Fusarium wilt in chickpea cultivars. Phytopathology 97:564-573.

49. Nelson, P. E., Tousson, T. A., and Cook, R. J. 1981. Fusarium: Diseases, Biology, and Taxonomy. The Pennsylvania University Press, University Park.

50. Nelson, P. E., Toussoun, T. A., and Marasas, W. F. O. 1983. Fusarium Species. An Illustrated Manual for Identification. Pennsylvania State University Press, University Park.

51. Nene, Y. L., Haware, M. P., and Reddy, M.V. 1978. Diagnosis of some wilt disorders of chickpea (Cicer arietinum L.). In: ICRISAT Information Bulletin, Vol. 3. Hyderabard, India.

52. Nitschke, E., Nihlgard, M., and Varrelmann, M. 2009. Differentiation of eleven Fusarium spp. isolated from sugar beet, using restriction fragment analysis of a polymerase chain reaction-amplified translation elongation factor $1 \alpha$ gene fragment. Phytopathology 99:921-929.

53. O’Donnell, K., Cigelnik, E., and Nirenberg, H. I. 1998. Molecular systematics and phylogeography of the Gibberella fujikuroi species complex. Mycologia 90:465-493.

54. O'Donnell, K., Kistlerr, H. C., Cigelnik, E., and Ploetz, R. C. 1998. Multiple evolutionary origins of the fungus causing panama disease of banana: concordant evidence from nuclear and mitochondrial gene genealogies. Proc. Nat. Acad. Sci. USA 95:2044-2049.

55. Rajeswara Rao, B. R., Bhattacharya, A. K., Singh, H. B., and Mallavarapu, G. R. 1999. The impact of wilt disease on oil yield and quality of two cultivars of rose-scented geranium (Pelargonium species). J. Essent. Oil Res. 11:769-775

56. Riccioni, L., Haegi, A., and Valvassori, M. 2008. First report of vascular wilt caused by Fusarium redolens on lentil in Italy. Plant Dis. 92:1132.

57. Schroers, H.-J., O’Donnell, K., Lamprecht, S. C., Kammeyer, P. L., Johnson, S., Sutton, D. A., Rinaldi, M. G., Geiser, D. M., and Summerbell, R. C 2009. Taxonomy and phylogeny of the Fusarium dimerum species group. Mycologia 101:44-70.

58. Subramanian, C. V. 1971. Hyphomycetes. An Account of Indian Species, Except Cercosporae. Indian Council for Agricultural Research, New Delhi.

59. Trapero-Casas, A., and Jiménez-Díaz, R. M. 1985. Fungal wilt and root rot diseases of chickpea in southern Spain. Phytopathology 75:1146-1151.

60. Visser, C., Wingfield, M. J., Wingfield, B. D., and Yamaoka, Y. 1995. Ophiostoma polonicum is a species of Ceratosystis sensu stricto. Syst. Appl. Microbiol. 18:403-409.

61. Waalwijk, C., Baayen, R. P., de Koning, J. R. A., and Gams, W. 1996. Ribosomal DNA analyses challenge the status of Fusarium sections Liseola and Elegans. Sydowia 48:90-104.

62. Waalwijk, C., de Koning, J. R. A., and Gams, W. 1996. Discordant groupings of Fusarium spp. from sections Elegans, Liseola and Dlaminia based on ribosomal ITS1 and ITS2 sequences. Mycologia 88:361-368.

63. Westerlund, F. V., Campbell, R. N., Jr., and Kimble, K. A. 1974. Fungal root rots and wilt of chickpea in California. Phytopathology 64:432-436.

64. White, T. J., Bruns, T., Lee S., and Taylor, J. W. 1990. Amplification an direct sequencing of fungal ribosomal RNA genes for phylogenetics. Pages 315-322 in: PCR Protocols: A Guide to Methods and Applications. M. A Innis, D. H. Gelfand, J. J. Sninsky, and T. T. White, eds. Academic Press Inc., New York.

65. Wong, J. Y., and Jeffries, P. 2006. Diversity of pathogenic Fusarium populations associated with asparagus roots in decline soils in Spain and the UK. Plant Pathol. 55:331-342.

66. Ypema, H. L., Van De Pol, P. A., and Bollen, G. J. 1987. Black rot of stentlings of roses: a disease caused by various soil fungi. Sci. Hortic. 33:269-280. 